\title{
Comparison of Peak Expiratory Flow Rate between Android and Gynoid Pattern Obesity in Females
}

\author{
Shruti Shah ${ }^{1}$, Pratibha Gaikwad ${ }^{2}$ \\ ${ }^{1}$ MPT (Cardiovascular and Respiratory Sciences) Lokmanya Tilak Municipal Medical College and General \\ Hospital, Sion, Mumbai, India \\ ${ }^{2}$ MPT (Cardiovascular and Respiratory Sciences) Associate Professor, Lokmanya Tilak Municipal Medical \\ College and General Hospital, Sion, Mumbai, India
}

Corresponding Author: Shruti Shah

\begin{abstract}
Title: Comparison of Peak Expiratory Flow Rate between Android and Gynoid Pattern Obesity in Females.

Aim: To assess comparison of PEFR between Android and Gynoid Pattern Obesity in Females. Objectives: To assess Peak Expiratory Flow Rate in Android Pattern, Gynoid Pattern of Obesity in Females and compare Peak Expiratory Flow Rate between Android and Gynoid Pattern Obesity in Females.

Methodology: 100 Female Obese Subjects with BMI> 30 in the Age Group between 20-40 yrs living a sedentary lifestyle were recruited with incidental sampling over the period of 1 year duration and allocated to Android $(n=50)$ and Gynoid $(n=50)$ groups on the basis of Adiposity Markers like BMI, Height, Weight, Waist Circumference (WC), Hip Circumference (HC), WHR - Waist Hip Ratio (WHR) and Waist to Height Ratio (WtHR). PEFR was recorded by taking 3 readings and the highest among them chosen.

Results: Pearson correlation test and Linear Regression was done between PEFR \& BMI, PEFR \& WHR and PEFR \& WHtR. Using an Unrelated t Test, results were found to be Significant ( $<<0.05)$ between PEFR in Both the Groups.

Conclusion: The study establishes that there is a difference in PEFR between Android and Gynoid Pattern of Obesity in Females and PEFR in Gynoid Pattern is 5\% better than PEFR in the Android Pattern Obesity in Females.
\end{abstract}

Keywords: Obesity, Android, Gynoid, PEFR, BMI, WHR, WtHR, WC, HC.

\section{INTRODUCTION}

WHO defines obesity as "A condition with excessive fat accumulation in the body to the extent that the health and well-being are adversely affected." ${ }^{[1]}$ Prevalence of obesity is $45.6 \%$ and is higher among women in India. ${ }^{[2,3,4,5,6,7]}$

The effects of obesity on the respiratory system are often underappreciated. ${ }^{[8]}$ Respiratory function is determined by the complex interaction of the lungs, chest wall, and respiratory muscles. In Obesity, there is excessive accumulation of fat which alters the relationship between the lungs, chest wall, and diaphragm leading to respiratory muscle inefficiency and reduction in Lung volumes and capacities. ${ }^{[9]}$ In Obese individuals due to respiratory muscle inefficiency, decreased functional reserve capacity and expiratory reserve volume, the demand for ventilation and breathing workload are increased. These often result in a ventilation-perfusion (V/Q) mismatch which is also a cause of alveolar hypoventilation. [10] Obesity is believed to influence the pulmonary function mechanically by changing lung compliance, work of 
breathing, and the elastic recoil. ${ }^{[11,12,13,14]}$ The site of fat accumulation is crucial in determining the effect of obesity on respiratory system mechanics. ${ }^{[8]}$

Two distinct patterns of obesity are recognized in the general population: Central and Peripheral obesity. ${ }^{[15}$ Central fat distribution describes the distribution of human adipose tissue mainly around the trunk and upper body, in areas such as the abdomen, chest, shoulder, and nape of the neck. ${ }^{[16]}$ This pattern may lead to an "appleshaped" body or Android obesity and is more common in males than in females. ${ }^{[17]}$

In other cases, an ovoid shape forms which does not differentiate between men and women. Generally, during early adulthood, females tend to have a more peripheral fat distribution such that their fat is evenly distributed over their body. However, it has been found that as females age, bear children, and approach menopause, this distribution shifts towards the android pattern of fat distribution [18] resulting in a $42.1 \%$ increase in android body fat distribution in postmenstrual women. ${ }^{[17]}$ This could potentially provide evolutionary advantages in child- bearing females such as lowering a woman's center of gravity making her more stable when carrying an offspring. ${ }^{[16]}$

Android fat distribution is contrasted with gynoid fat distribution; fat around the hips, thighs, and bottom, causing a "pearshape". [19] Peripheral obesity is more common in women than men, with adiposity located peripherally in the subcutaneous tissue. ${ }^{[15]}$ There are differences in android and gynoid fat distribution among individuals, which relates to various health issues. People with android obesity have higher hematocrit and red blood cell count and higher blood viscosity than people with gynoid obesity. Blood pressure is also higher in those with android obesity. Android body fat distribution is related to high cardiovascular disease and mortality rate. ${ }^{[19]}$ Android or abdominal obesity is associated with worsening lung function and respiratory symptoms. ${ }^{[20]}$ Peripheral obesity is associated with fewer medical complications and better lung function. ${ }^{[15]}$

Adiposity markers like Body Mass Index, Waist Circumference, Waist Hip Ratio, and Waist Height Ratio help in better prediction of Body Fat between Android and Gynoid Pattern. There is substantial evidence providing that fat distribution is a better predictor of cardiovascular disease than the degree of obesity. [21, 22, 23, 24, 25] BMI alone does not provide sufficient information about the bodily distribution of fat mass (FM). ${ }^{[20,26]}$ Thus, regional fat distribution rather than overall fat volume has been considered to be more important in understanding the link between obesity and metabolic disorders.

The size of a person's waist or waist circumference indicates abdominal obesity. Excess abdominal fat is a risk factor for developing heart disease and other obesity related diseases. The National Heart, Lung, and Blood Institute (NHLBI) classify the risk of obesity-related diseases as high if men have a waist circumference greater than $102 \mathrm{~cm}$ (40 in) and women have a waist circumference greater than $88 \mathrm{~cm}$ (35 in). Various medical conditions are also associated with elevated WC. These include cardiovascular diseases (atherosclerosis, ischemic heart disease, stroke, hyperlipidemia, and hypertension), type 2 diabetes mellitus, and metabolic syndrome. $[26,27]$

WHR is used as a measurement of obesity, which in turn is a possible indicator of other more serious health conditions. The WHO states that abdominal obesity is defined as a waist-hip ratio above 0.90 for males and above 0.85 for females or a body mass index (BMI) above 30.0. ${ }^{[28]}$ Studies that focused on waist circumference (WC) found that elevated waist-to hip-ratio and abdominal height had a good correlation with impaired lung function. ${ }^{[20,26,29]}$

A person's waist-to-height ratio (WHtR), also called waist to-stature ratio (WSR) is defined as their waist circumference divided by their height, both measured in the same units. The WHtR is a 
measure of the distribution of body fat. Higher values of WHtR indicate a higher risk of obesity-related cardiovascular diseases and are correlated with abdominal obesity. ${ }^{[30]}$

PEFR as a measurement of ventilatory function was introduced by Hadorn in 1942 and was accepted in 1949 as an index of spirometry. ${ }^{[32]}$ By definition, it is "The largest expiratory flow rate achieved with a maximally forced effort from a position of maximal inspiration, expressed in liters/min. It is effort dependent and reflects mainly the caliber of the bronchi and larger bronchioles, which are subjected to reflex bronchoconstriction. [33] The average PEFR of healthy young Indian males and females is around 500 and 350 $1 \mathrm{pm}$ respectively. The PEFR reaches a peak at about 18-20 years, maintains this level up to about 30 years in males, and about 40 years in females, and then declines with age. [34]

About $15-20 \%$ of body fat for men and $25 \%$ of body fat for women are generally accepted as 'normal', but 10 to $20 \%$ of excess body fat over the ${ }^{[35]}$ usual values is generally considered to be "obesity". Obesity has a clear potential to have a direct effect on respiratory wellbeing since it increases oxygen consumption and carbon dioxide production, while at the same time it stiffens the respiratory muscles, decreases PEFR and [36] increases the mechanical work of breathing. The significant reduction in PEFR in obese subjects may be explained based on an of accumulation of adipose tissue around the rib cage, abdomen and in the visceral cavity that results in a shift in the balance of inflationary and deflationary pressure on the lungs as reported by J.T. Sharp et al. ${ }^{[37]}$ These obese subjects may also have limited lung expansion and airflow because of the restricted downward movement of the diaphragm due to increased abdominal adipose tissue leading to significantly reduced PEFR. ${ }^{[38]}$

Previous studies have proved that reduction in Pulmonary Function has a relation with Obesity. The distribution of fat induced by the weight gain affects the risks associated with obesity, and the kind of disease that results. It is therefore useful, to be able to distinguish between those at increased risk as a result of abdominal fat distribution or Android obesity from those with the less serious Gynoid fat distribution, in which fat is more evenly and peripherally distributed around the body. ${ }^{[39]}$ To our knowledge, no studies are been done to compare the effects of Peak Expiratory Flow Rate between Android and Gynoid pattern of Obesity in Females between 2040 years. Pulmonary Function is measured by PFT (Spirometry) which is expensive and diagnosed only when symptomatic at a later stage. Peak Expiratory Flow Rate is an inexpensive and practical way to measure Lung Function which can differenciate healthy Respiratory system from a diseased one, detect early warning signs in at-risk populations and can be used as an early intervention to prevent Cardiovascular and Respiratory complications in Females. Prognostically, it can help us in assessing the degree/severity of disease and disability, evaluating the effectiveness of treatment/exercise program and determining further treatment goals. It also helps young female adults establish the habit of periodic medical evaluation because disease and illness such as obesity and cardiovascular diseases can be identified in their earliest stages when chances of successful treatment are higher. ${ }^{[40]}$

Thus, this study is undertaken to compare the effect of Peak Expiratory Flow Rate between Android and Gynoid Obesity in Females.

AIM: To assess comparison of PEFR between Android and Gynoid Pattern Obesity in Females.

\section{OBJECTIVES:}

1) To assess Peak Expiratory Flow Rate in Android Pattern of Obesity in Females.

2) To assess Peak Expiratory Flow Rate in Gynoid Pattern of Obesity in Females. 

females.

3) To compare Peak Expiratory Flow Rate IV. between Android and Gynoid Pattern Obesity in Females.

\section{Operational Definitions:}

1. Obesity: A condition with excessive fat accumulation in the body to the extent that the health and well-being are adversely affected. ${ }^{[1]}$

2. Android Obesity: It is the distribution of VII. adipose tissue around the abdomen, chest, shoulder and nape of the neck related to high cardiovascular disease and mortality rate. ${ }^{[16,19]}$

3. Gynoid Obesity: It is the distribution of adipose tissue around the hips, thighs and bottom related to low cardiovascular disease and mortality rate. ${ }^{[19]}$

4. Physically Inactive: Adults are classified as inactive if they did not report any sessions of light to moderate or vigorous leisure-time physical activity of at least 10 minutes a day. ${ }^{[61]}$

\section{MATERIALS \& METHODS}

I. Type of study design: Cross sectional Study Design

II. Setting (Location of Study): Physiotherapy Department, Tertiary Care Hospital

III. Study Population: Female subjects with Obesity > 30
Sample Size: 50 in Each Group

(Android and Gynoid)

$\mathrm{N}=4 \mathrm{PQ} / \mathrm{R} 2$

$\mathrm{P}=$ Proportion $=0.5$

$\mathrm{Q}=(\mathrm{P}-\mathrm{Q})=0.5$

$\mathrm{R}=$ Error $=0.1$

V. Sampling Technique: Purposive Sampling

VI. Duration of Study: 6-9 Months

II. Method of selection of study subjects: Inclusion Criteria:

$>$ Female subjects between 20 and 40 years

$>$ Female subjects with Obesity with BMI $>30$

$>$ Female subjects with a Sedentary lifestyle

$>$ Individuals willing to participate in the study

\section{Exclusion criteria:}

$>$ Known cases of Respiratory and Cardiac disorders

$>$ Thoracic and Abdominal Surgery

$>$ Pregnancy and Postpartum period about 8-10 weeks

$>$ Smokers, Alcohol and Tobacco consumption

\section{Materials:}

1. Peak Expiratory Flow Rate

2. Weighing Scale

3. Measuring Tape

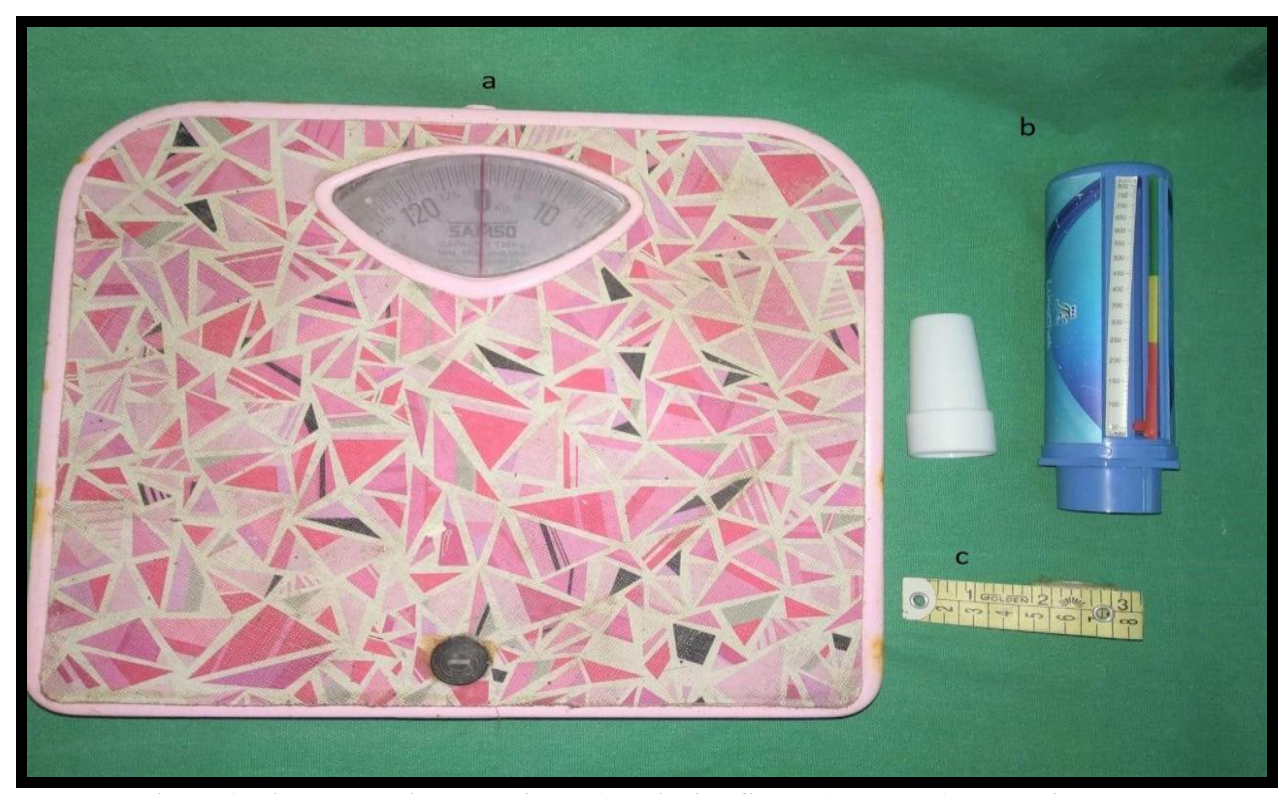

Figure 1: Picture showing materials - a) Weighing Scale, b) PEFR, c) Measuring Tape 


\section{METHODOLOGY}

$>$ Institutional ethics committee approval was taken.

$>$ Sample Size of 100 was selected and Selection of participants was done depending upon the inclusion and the exclusion criteria and appropriate sampling technique.

$>$ Female subjects with Obesity coming to the Physiotherapy OPD for Weight Management and relatives accompanying them who had Obesity were taken for the study.

$>$ They were explained about the study in the language they understand.

$>$ Informed consent was taken.

$>$ Participants assessment was taken as follows:

1. Demographic data: Name, Age, Gender

2. Adiposity Markers: BMI - Height, Weight, Waist Circumference, Hip Circumference, WHR - Waist Hip Ratio, WtHR - Waist to Height Ratio

3. Peak Expiratory Flow Rate: Three Readings

Adiposity Markers to classify into Android and Gynoid Obesity:

a) Height $(\mathrm{H})$ : Measured to the nearest 0.5 $\mathrm{cm}$ with the help of a height scale. ${ }^{[62]}$

b) Weight (W): Measured by a weighing scale in kilograms without shoes, and with subjects wearing light weight clothes. ${ }^{[62]}$

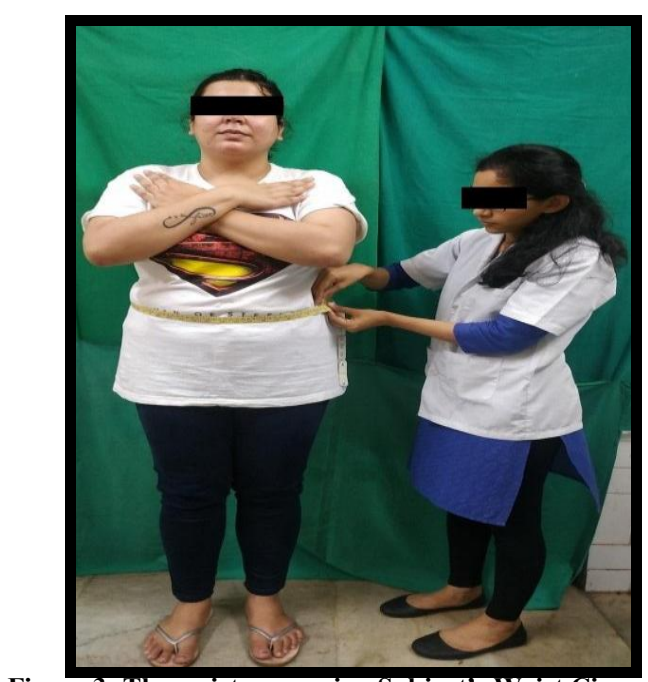

Figure 3: Therapist measuring Subject's Waist Circumference c) BMI: Calculated using Quetelet's formula (BMI = weight in kilograms / height in meter square). ${ }^{[62]}$

d) Waist Circumference (WC): In erect posture with the feet apart by 25 to 30 $\mathrm{cm}$ on light clothing, using a measuring tape at the level of umbilicus. ${ }^{[53]}$

e) Hip Circumference (HC): Measured at the widest part of the buttocks with the legs and feet together. ${ }^{[62]}$

f) Waist Hip Ratio (WHR): Calculated by dividing WC by HC. ${ }^{[62]}$

g) Waist to Height Ratio (WHtR): Calculated by dividing WC by Height. [62]
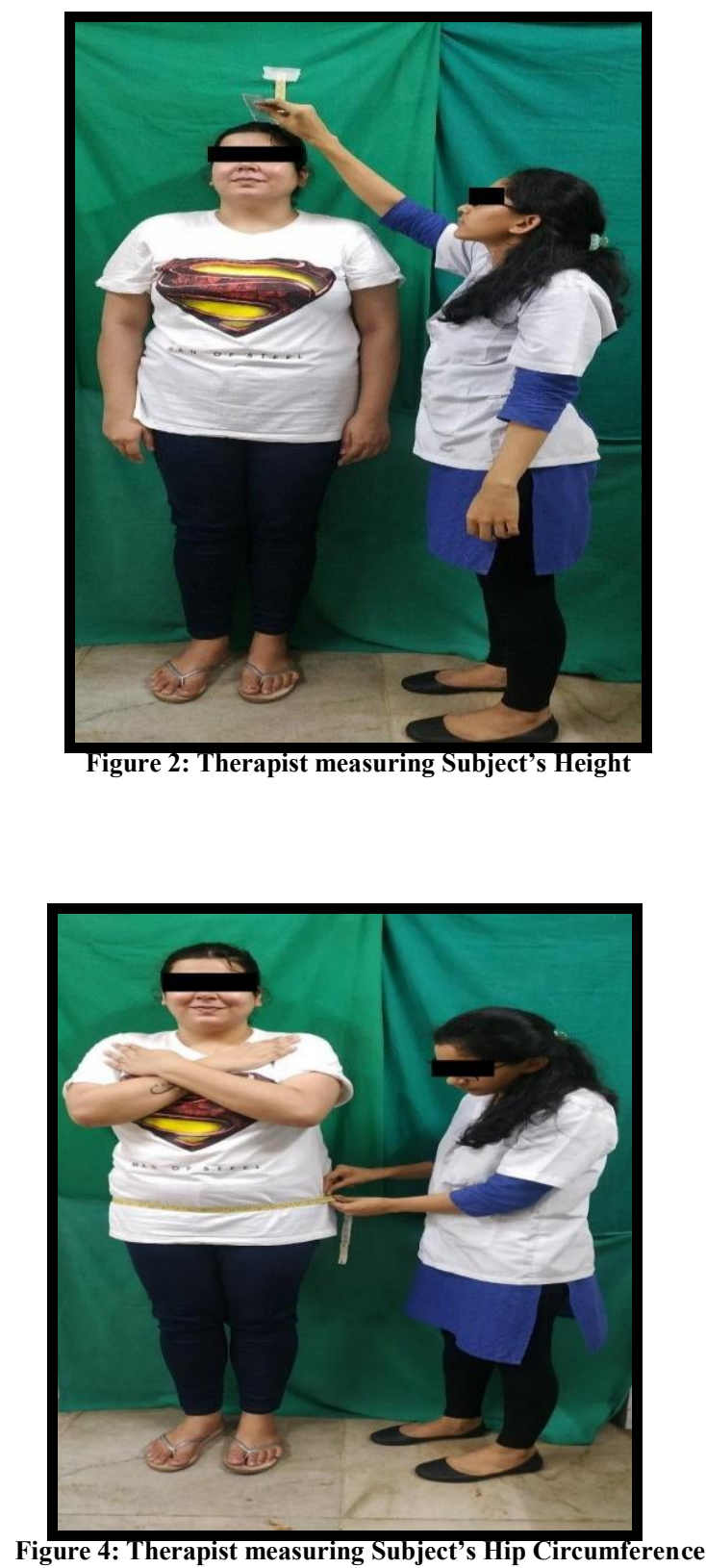


\section{Peak Expiratory Flow Rate:}

Recorded using Wright's mini peak flow meter (Clement \& Clarke, UK) in standing position. After adequate rest, subjects were instructed to take a deep breath and exhale as forcefully as possible in one single blow into the instrument. Three satisfactory readings were taken. Sufficient care was taken to ensure that a tight seal is maintained between the lips and mouthpiece. The highest among the three were considered as the Peak Expiratory Flow Rate. ${ }^{[62]}$

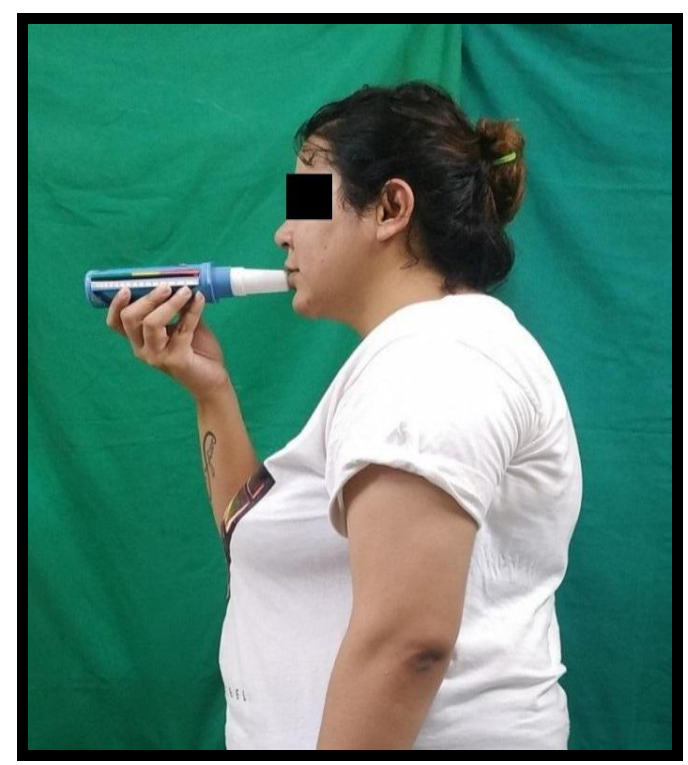

Figure 5: Subject using PEFR device

\section{INTERPRETATION}

\section{BMI $^{[63]}$}

Obese Type 1 (Obese)

Obese Type 2 (Morbid Obese)

Obese Type 3 (Super Obese)

Waist Circumference: $>88 \mathrm{~cm}$ - Indicated Obesity-related cardiovascular diseases and was correlated with Abdominal obesity. ${ }^{[20,}$ 27]

Hip Circumference: > $91 \mathrm{~cm}$ - Indicated cardiovascular and coronary heart diseases in women. ${ }^{[64]}$

WHR: > 0.85 - Indicated Android Obesity. [28]

$<0.85$ - Indicated Gynoid Obesity. ${ }^{[28]}$

WHtR: > 0.5 - Indicated Obesity-related cardiovascular diseases and was correlated with Abdominal obesity. ${ }^{[30]}$

PEFR: Normal Range: 0 - $500 \mathrm{~L} / \mathrm{min}$.

- Data analysis was done.
- Statistics Analysis was carried out using appropriate technique.

\section{Parameters studied were:}

- PEFR

- Adiposity Markers

IX. Data Collection Tool: Peak Expiratory Flow Rate (PEFR)

\section{RESULTS \& DISCUSSION}

DATA ANALYSIS:

- All data analysis was performed using GraphPad Prism 8.3.1 software.

- All the numerical data was tested for Normal Distribution and the data followed normal distribution pattern. Pearson Correlation, a parametric test was used to find out the correlations between variables.

- Linear Regression was then performed among the variables.

- Unrelated t test was used to compare Peak Expiratory Flow Rate between Android and Gynoid Pattern Obesity in Females.

- All tests were performed considering 95\% confidence intervals and significance at 0.05 .

- Bar charts and Graphs were used for visual representation of the analyzed data.

\section{Observation 1: Classification of BMI} According to Type in Android Group

Graph 1: Classification of BMI Acc to Type in Android Group

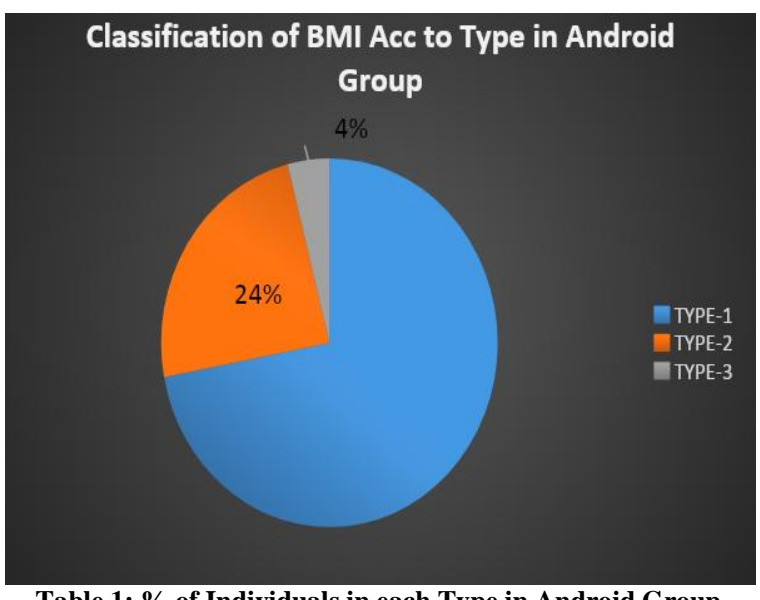


Shruti Shah et.al. Comparison of peak expiratory flow rate between android and gynoid pattern obesity in females.

\begin{tabular}{|l|l|}
\hline $\begin{array}{l}\text { Type of } \\
\text { Obesity }\end{array}$ & $\begin{array}{l}\text { \% of Individuals in each Type in Android } \\
\text { Group }\end{array}$ \\
\hline Type 1 & $72 \%$ \\
\hline Type 2 & $24 \%$ \\
\hline Type 3 & $4 \%$ \\
\hline
\end{tabular}

Inference: The study shows that majority of the population in the Android group belonged to type 1 and minority in Type 3 .

\section{Observation 2: Classification of BMI Acc to Type in Gynoid Group \\ Graph 2: Classification of BMI Acc to Type in Gynoid Group}

\section{Table 2: \% of Individuals in each Type in Gynoid Group}

\begin{tabular}{|l|l|}
\hline $\begin{array}{l}\text { Type } \\
\text { Obesity }\end{array}$ & $\begin{array}{l}\text { \% of Individuals in each Type in Gynoid } \\
\text { Group }\end{array}$ \\
\hline Type 1 & $76 \%$ \\
\hline Type 2 & $20 \%$ \\
\hline Type 3 & $4 \%$ \\
\hline
\end{tabular}

Inference: The study shows that majority of the population in Gynoid group belonged to type 1 and minority in Type 3 .

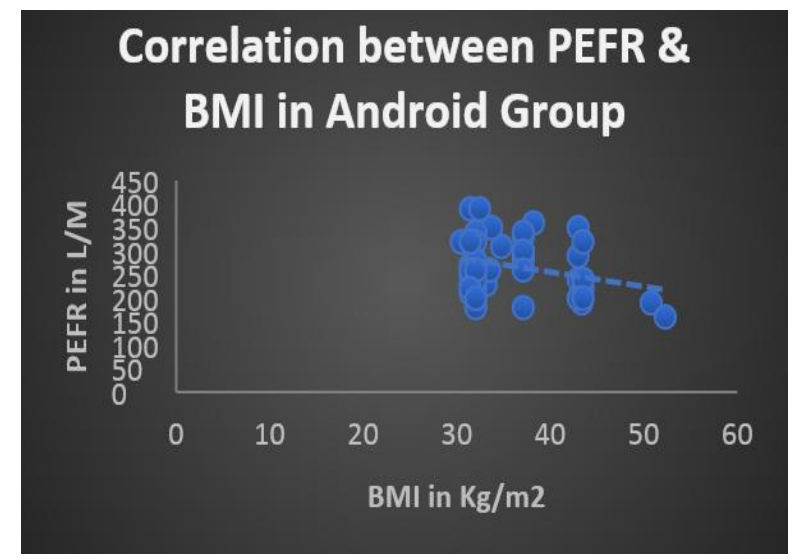

Table 3: Values of correlation between PEFR \& BMI in Android and Gynoid Group

\begin{tabular}{|l|l|l|}
\hline Parameters & $\begin{array}{l}\text { Values of Android } \\
\text { Group }\end{array}$ & $\begin{array}{l}\text { Values of Gynoid } \\
\text { Group }\end{array}$ \\
\hline $\mathrm{R}$ & -0.29 & -0.14 \\
\hline $\begin{array}{l}95 \% \text { confidence } \\
\text { Interval }\end{array}$ & -0.5323 to -0.02153 & -0.4033 to 0.1432 \\
\hline P value & 0.0178 & 0.1648 \\
\hline Significance & Yes & No \\
\hline Number of samples & 50 & 50 \\
\hline
\end{tabular}

\section{Inference:}

$>$ Using a Pearson product moment correlation test on the data $(\mathrm{r}=-0.29$, df $=48)$, the results were significant ( $\mathrm{p}<$ 0.025 for a one-tailed test). This means there is a negative correlation between PEFR and BMI (the higher the BMI, the

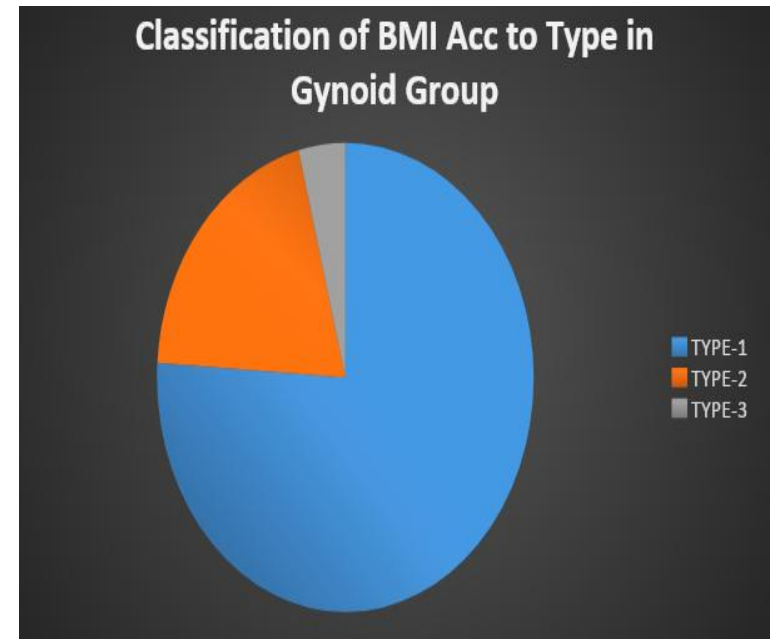

\section{Observation 3: Correlation between} PEFR and BMI in Both the Groups

Graph 3 \& 4: Correlation between PEFR \& BMI in Android and Gynoid Group

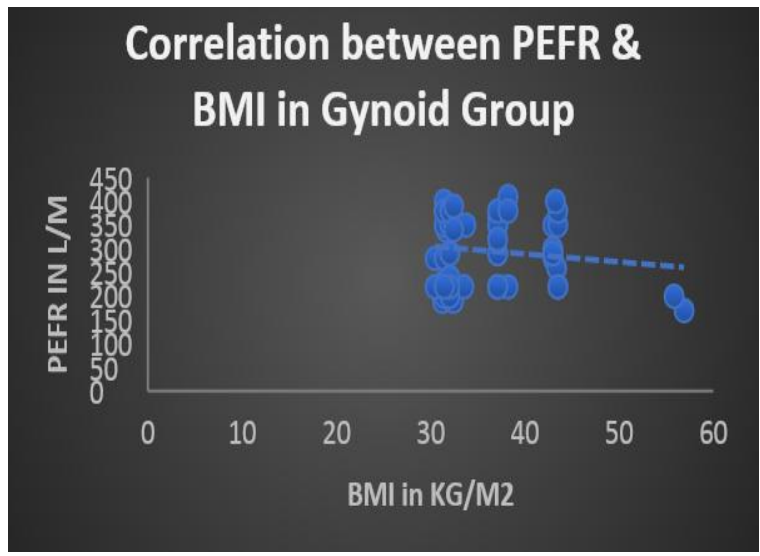

lower the range of PEFR) in the Android Group.

$>$ Using a Pearson product moment correlation test on the data $(\mathrm{r}=-0.14$, df $=48)$, the results were not significant ( $\mathrm{p}$ $>0.025$ for a one-tailed test). This means there is a positive correlation between PEFR and BMI (the higher the BMI, the higher the range of PEFR) in the Gynoid Group.

\section{Observation 4: Correlation between} PEFR and WHR in Both the Groups Graph 5 \& 6: Correlation between PEFR \& WHR in Android and Gynoid Group 


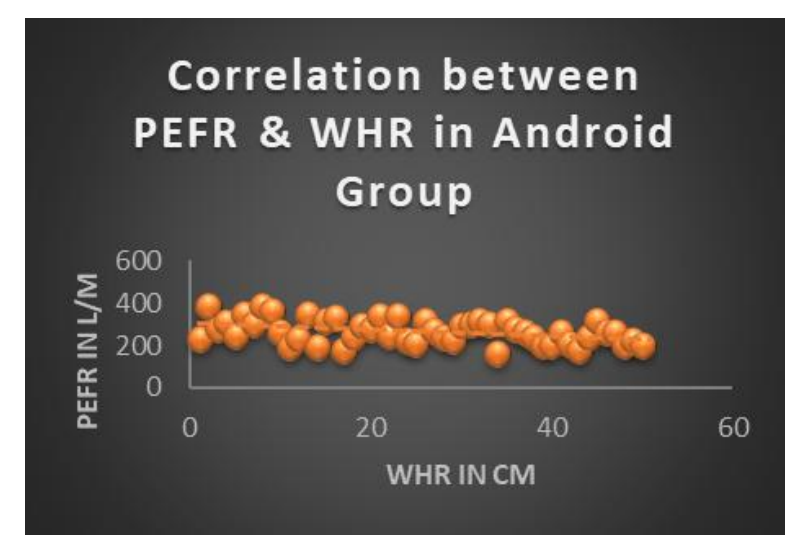

Table 4: Values of correlation between PEFR \& WHR in Android and Gynoid Group

\begin{tabular}{|l|l|l|}
\hline Parameters & $\begin{array}{l}\text { Values of Android } \\
\text { Group }\end{array}$ & $\begin{array}{l}\text { Values of Gynoid } \\
\text { Group }\end{array}$ \\
\hline $\mathrm{R}$ & -0.08096 & 0.3177 \\
\hline $\begin{array}{l}95 \% \text { confidence } \\
\text { Interval }\end{array}$ & -0.3514 to 0.2019 & 0.04314 to 0.5476 \\
\hline P value & 0.2881 & 0.0123 \\
\hline Significance & No & Yes \\
\hline Number of samples & 50 & 50 \\
\hline
\end{tabular}

\section{Inference:}

$>$ Using a Pearson product moment correlation test on the data $(\mathrm{r}=-0.08$, df $=48)$, the results were significant $(\mathrm{p}>$ 0.025 for a one-tailed test). This means there is a positive correlation between PEFR and WHR (the higher the WHR,

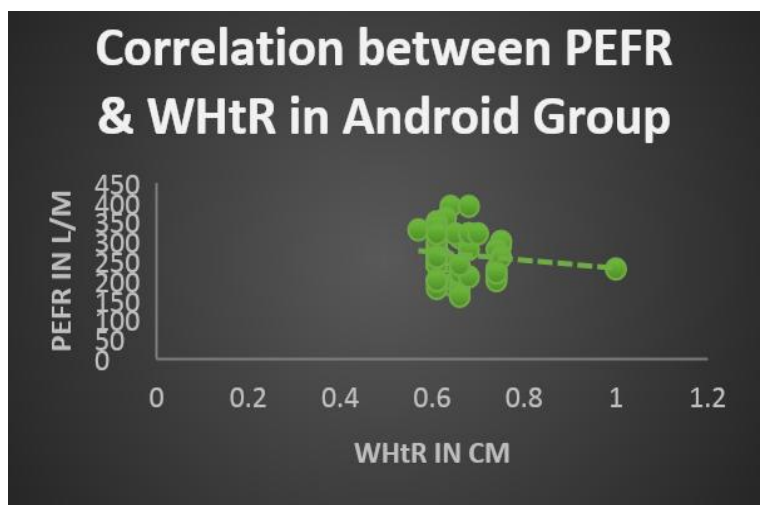

Table 5: Values of correlation between PEFR \& WHtR in Android and Gynoid Group

\begin{tabular}{|l|l|l|}
\hline Parameters & $\begin{array}{l}\text { Values of Android } \\
\text { Group }\end{array}$ & $\begin{array}{l}\text { Values of Gynoid } \\
\text { Group }\end{array}$ \\
\hline $\mathrm{R}$ & -0.1768 & 0.02702 \\
\hline $\begin{array}{l}95 \% \text { confidence } \\
\text { Interval }\end{array}$ & -0.4338 to 0.1068 & -0.2532 to 0.3031 \\
\hline P value & 0.1096 & 0.4261 \\
\hline Significance & No & No \\
\hline Number of samples & 50 & 50 \\
\hline
\end{tabular}

\section{Inference:}

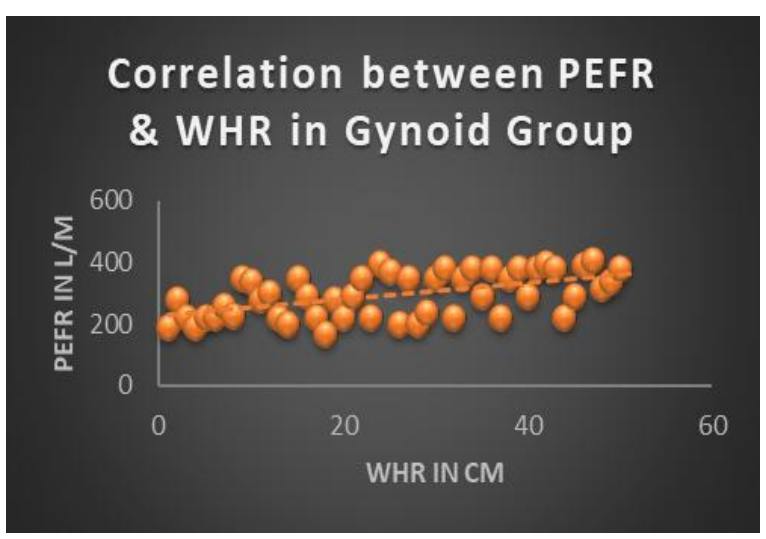

the higher the range of PEFR) in the Android Group.

$>$ Using a Pearson product moment correlation test on the data $(\mathrm{r}=0.31$, df $=48$ ), the results were not significant ( $\mathrm{p}$ $<0.025$ for a one-tailed test). This means there is a negative correlation between PEFR and WHR (the higher the WHR, the lower the range of PEFR) in the Gynoid Group.

\section{Observation 5: Correlation between} PEFR and WHtR in Both the Groups

Graph 7 \& 8: Correlation between PEFR \& WHtR in Android and Gynoid Group

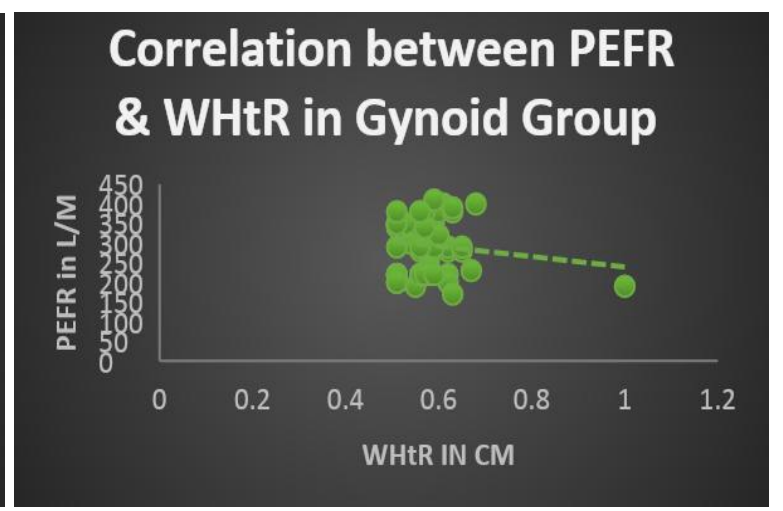

Using a Pearson product moment correlation test on the data $(r=-0.17$, df $=48$ ), the results were not significant ( $p$ $>0.025$ for a one-tailed test). This means there is a positive correlation between PEFR and WHtR (the higher the WHtR, the higher the range of PEFR) in the Android Group. 

females.

$>$ Using a Pearson product moment correlation test on the data $(\mathrm{r}=0.02$, df $=48)$, the results were not significant $(\mathrm{p}$ $>0.025$ for a one-tailed test). This means there is a positive correlation between PEFR and WHtR (the higher the WHtR, the higher the range of PEFR) in the Gynoid Group.

\section{Observation 6: Linear Regression in Both the Groups}

\begin{tabular}{|c|c|c|c|c|c|c|}
\hline & PEFR \& BMI & & PEFR \& WHR & & PEFR \& WtHR & \\
\hline Parameters & $\begin{array}{l}\text { Values of } \\
\text { Android Group }\end{array}$ & $\begin{array}{l}\text { Values of } \\
\text { Gynoid Group }\end{array}$ & $\begin{array}{l}\text { Values of } \\
\text { Android Group }\end{array}$ & $\begin{array}{l}\text { Values of } \\
\text { Gynoid Group }\end{array}$ & $\begin{array}{l}\text { Values of } \\
\text { Android Group }\end{array}$ & $\begin{array}{l}\text { Values of } \\
\text { Gynoid Group }\end{array}$ \\
\hline$\overline{\mathrm{R}^{2}}$ & 0.08886 & 0.01982 & 0.006554 & 0.1009 & 0.03127 & 0.00073 \\
\hline $\begin{array}{l}95 \% \quad \text { confidence } \\
\text { Interval Slope }\end{array}$ & $\begin{array}{lll}-0.05530 & \text { to } & - \\
0.002026 & & \end{array}$ & $\begin{array}{l}-0.03598 \\
0.01232\end{array}$ & $\begin{array}{l}-0.0001859 \text { to }- \\
0.0001046\end{array}$ & $\begin{array}{l}1.757 \mathrm{e}-005 \\
0.0002450\end{array}$ & $\begin{array}{ll}-0.0004249 & \text { to } \\
9.995 \mathrm{e}-005 & \end{array}$ & $\begin{array}{ll}-0.0001726 & \text { to } \\
0.0002080 & \end{array}$ \\
\hline $\mathrm{P}$ value & 0.0355 & 0.3295 & 0.5762 & 0.0246 & 0.2193 & 0.8522 \\
\hline Significance & Yes & No & No & Yes & No & No \\
\hline Number of samples & 50 & 50 & 50 & 50 & 50 & 50 \\
\hline
\end{tabular}

\section{Inference: Linear Regression between} PEFR and BMI

$>$ Using Linear Regression test on the data $\left(\mathrm{r}^{2}=0.08\right.$, df $\left.=48\right)$, the results were significant $(\mathrm{p}<0.025$ for a one-tailed test) in the Android Group.

$>$ Using Linear Regression test on the data $\left(\mathrm{r}^{2}=0.01, \mathrm{df}=48\right)$, the results were not significant $(\mathrm{p}>0.025$ for a one-tailed test) in the Gynoid Group.

\section{Linear Regression between PEFR and WHR}

$>$ Using Linear Regression test on the data $\left(\mathrm{r}^{2}=0.006, \mathrm{df}=48\right)$, the results were not significant $(\mathrm{p}>0.025$ for a one-tailed test) in the Android Group.

$>$ Using Linear Regression test on the data $\left(\mathrm{r}^{2}=0.10, \mathrm{df}=48\right)$, the results were significant $(\mathrm{p}<0.025$ for a one-tailed test) in the Gynoid Group.

\section{Linear Regression between PEFR and WHtR}

$>$ Using Linear Regression test on the data $\left(r^{2}=0.03, \mathrm{df}=48\right)$, the results were not significant $(\mathrm{p}>0.025$ for a one-tailed test) in the Android Group.

$>$ Using Linear Regression test on the data $\left(\mathrm{r}^{2}=0.0007, \mathrm{df}=48\right)$, the results were not significant ( $p>0.025$ for a onetailed test) in the Gynoid Group.

\section{Observation 9: Unpaired T Test between PEFR in Both the Groups}

Graph 9: Unpaired T Test between PEFR in Both the Groups

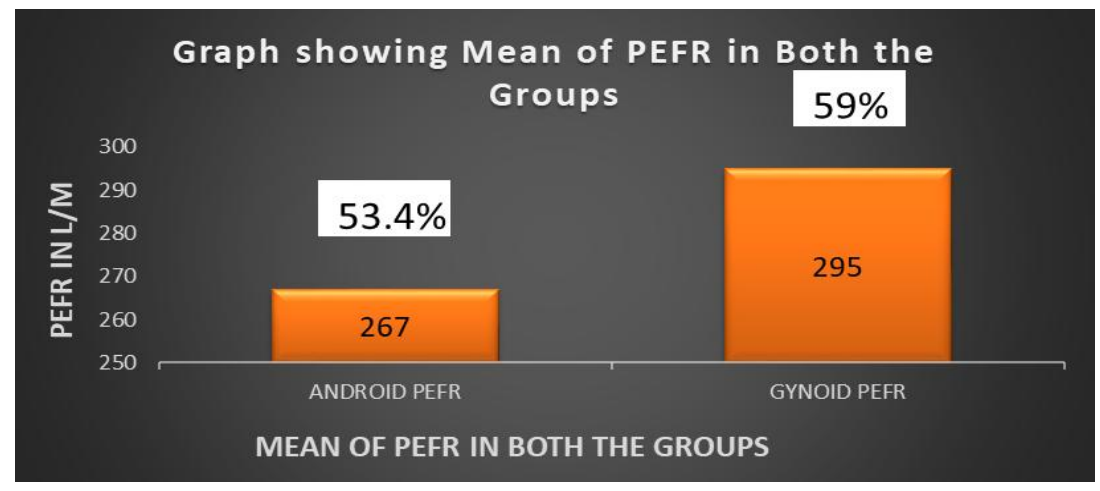

Table 6: Mean Values of PEFR in Android and Gynoid Group

\begin{tabular}{|l|l|}
\hline Parameters & Values \\
\hline $\mathrm{R}^{2}$ & 0.08886 \\
\hline $95 \%$ confidence Interval Slope & 1.996 to 54.00 \\
\hline $\mathrm{P}$ value & 0.04452 \\
\hline Significance & Yes \\
\hline Number of samples & 50 \\
\hline
\end{tabular}

\section{Inference:}

$>$ Using an Unrelated $\mathrm{t}$ Test on the data $(\mathrm{t}$ $=2.137, \mathrm{df}=98)$ the results were found 
to be Significant $(\mathrm{p}<0.05$ for a onetailed hypothesis)

$>$ The Null hypothesis can therefore be rejected. This means that there is a difference in Peak Expiratory Flow Rate between Android and Gynoid Obesity in Females.

$>$ The PEFR in the Gynoid Group is 5.6\% better than PEFR in the Android Group.

\section{DISCUSSION}

The results of the present study, Comparison of PEFR between Android and Gynoid Obesity in Females in the age group of 20-40 years implies that Obesity detriments the lung functions in Young Females having an Android pattern of Fat distribution more when compared to Gynoid pattern. Various mechanisms were speculated for them, which were as follows:

\section{Observations 1, 2: $\quad$ Represent classification of BMI According to Type in Both the Groups.}

Graphs 1, 2 \& Tables 1, 2 show that the Maximum no of the subjects belonged to Type 1 obesity and the minimum in Type 3 obesity. This suggests that young Females are mostly Over-weight and in Class 1 Obesity i.e. with corrective and preventive measures, they can come into the Normal BMI Category. Thus, making Screening an important part of the assessment in this age group of 20-40 years and reducing the comorbidities associated with Obesity.

There is conclusive evidence that Obesity located in the central abdominal parts of the body is statistically associated with several metabolic derangements such as insulin resistance, hyperinsulinemia, noninsulin-dependent diabetes mellitus, hyperlipidemia, and hypertension. The mechanism might be due to lipolytically sensitive abdominal depots providing excess free fatty acids to a muscle tissue that has a decreased capacity for their oxidation. The excessive exposure of tissues to fatty acids impairs insulin function and increases blood insulin levels. All this ultimately results in reduced insulin sensitivity making a person insulin resistant. This in turn results in hyper-insulinemia, which might be the starting point for most of other metabolic derangements. ${ }^{[69]}$

Truncal obesity is associated with high blood insulin levels, which also increases the activity of lipoprotein lipase and fat storage and may indirectly cause overeating. Fat cells from the upper body seem to be functionally different from fat cells in the lower body. Primarily by hypertrophy (increase in the size of cells) of the existing cells, whereas lower body fat deposition is by hyperplasia (increase in the number of cells). Reducing the number of cells in the lower body hyperplastic depot is difficult compared to reduce truncal obesity where there is increase in the size of adipocytes. This may explain the weight loss difficulties of many women with lower body obesity. ${ }^{[65]}$

The present study was carried out in females having an Android pattern of Fat distribution and those having Gynoid Type. Obesity may lead to intra-abdominal adipose accumulation, which exerts a load on cardiac and respiratory muscles especially the diaphragm, which may cause dyspnea. ${ }^{[66]}$ Accumulation of adipose tissue around the abdomen, visceral cavity, and around rib cage may produce an imbalance between inflationary and deflationary pressure on the lungs leading to a reduction in PEFR. The probable reason for a decrease in PEFR in obese may be the fat deposition in the abdomen which may resist the movement of the diaphragm and in turn, reduce the vertical diameter of the thoracic cavity. Due to this compliance of the lungs and the thoracic cavity may decrease and increases the load on muscles of respiration, leading to a reduction in lung volumes and flow rates, especially PEFR. ${ }^{[67]}$ Thus it is evident from the present study that obesity significantly affects the pulmonary functions which may give rise to long term complications and may lead to early morbidity and mortality. ${ }^{[68]}$ 


\section{Observation 3: Shows Correlation between PEFR and BMI in Both the Groups}

From Graphs 3, 4 and Table 3, using a Pearson product-moment correlation test on the data $(\mathrm{r}=-0.29$, df $=48)$, the results were significant $(\mathrm{p}<0.025$ for a one-tailed test). This means there is a negative correlation between PEFR and BMI (the higher the BMI, the lower the range of PEFR) in the Android Group. King GG et also observed a strong relationship between body mass index and both lung volume and airway caliber in obese individuals which reflects that, with increasing body mass index, airways were narrower than expected based on the reduction in lung volume, suggesting that there were structural ${ }^{[69]}$ or functional changes in the airways.

According to a study, obesities which prevail on the upper half of the body, and which are hypersthenic, (excessive muscle tone) hypermetabolic, (increased rate of metabolic activity often abnormal) hyperemic, (excess of blood in a body part) and orthohydropexic; the fat overload there is accompanied by muscular hypertrophy generally linked to a robust skeleton. The predominance of the aqueous anabolism concerns the blood much more than it does the interstitial plasma. Vital prognosis is above all linked to the circulatory consequences of the plethora: red hypertension, premature atherosclerosis, cardiorenal and cerebral failure, etc. Red hypertension is indeed a usual manifestation, precocious, and parallel to the extent of fat overload. Hyperglycemia and diabetes are frequent and they also follow the development of adipose hypertrophy. ${ }^{[70]}$

An excess of abdominal fat is considered unfavorable, because visceral fat is thought to be more metabolically active, causing dysmetabolism of fatty acids and increased influx of free fatty acids into the splanchnic circulation. [71, 72] Moreover, adipose tissue has the same features as endocrine organs in terms of secreting cytokines, and visceral adipocytes secrete greater quantities of pro-inflammatory cytokines than does subcutaneous adipose tissue. [73, 74] Through these mechanisms, excess visceral obesity is hypothesized to cause insulin resistance and an atherogenic profile. Obesity itself and especially the pattern of body fat distribution have independent effects on PEFR in young adult females. As adipose tissue accumulates in excess amounts a variety of alterations and adaptations in cardiorespiratory structure and function occur even in the absence of co-morbidities. Hence, obesity may affect the heart and lungs through its influence on known risk factors such as dyslipidemia, hypertension, glucose intolerance, obstructive sleep apnea/hypoventilation. ${ }^{[75]}$

Using a Pearson product momentcorrelation test on the data $(\mathrm{r}=-0.14$, df $=$ 48 ), the results were not significant ( $\mathrm{p}>$ 0.025 for a one-tailed test). This means there is a positive correlation between PEFR and BMI (the higher the BMI, the higher the range of PEFR) in the Gynoid Group. Obesities, which are predominant on the lower half of the body are hyposthenic, (tall, thin) hypometabolic, (abnormally low metabolic rate) hypohemic, (too little blood) and hyperhydropexic (non-sugar antidiabetes). The circulatory system there is secure from plethora as aqueous hyperanabolism (promoting metabolic activity) is not effected towards the circulating blood but towards the interstitial plasma. Hypertension there is rare, contingent, independent of the degree of obesity and then identical - in its determination and evolution - to the pale hypertension of thin persons and subjects of normal weight. Glycoregulation disturbances are also rare and independent of fat overload. Complications are directly linked to this latter and its mechanical consequences. ${ }^{[70]}$ A gynoid obesity profile, where adipose tissue accumulates around the hips, is thought to protect against CVD. $[76,77]$

The primary factors that affect PEFR are the strength of the expiratory muscles generating the force of contraction, the 
elastic recoil pressure of the lungs, and the airway size. Accumulation of fat in and around the ribs, the diaphragm, and the abdomen results in a reduction in chest wall compliance. $^{[78]}$ Zerah et al., ${ }^{[79]}$ studied airway resistance in mild, moderate, and morbidly obese individuals and confirmed that both respiratory resistance and airway resistance rose significantly with the level of obesity. These findings suggest that in addition to the elastic load, obese individuals must overcome increased airway resistance resulting from a reduction in lung volumes due to obesity.

Since we got a positive correlation of PEFR with Gynoid obesity, it could mean that people with gynoid obesity present with a greater strength of expiratory muscles thus generating a greater force of contraction and yielding a higher PEFR value when compared to those of the Android type.

\section{Observation 4: Shows Correlation between PEFR \& WHR in Android and Gynoid Group}

Graphs 5, 6 \& Table 4, represent Pearson product-moment correlation test on the data $(\mathrm{r}=-0.08, \mathrm{df}=48)$, the results were significant $(p>0.025$ for a one-tailed test). This means there is a positive correlation between PEFR and WHR (the higher the WHR, the higher the range of PEFR) in the Android Group. High WC is supposed to hinder the diaphragm expansion, which controls the respiratory activity. Increased abdominal mass or abdominal adiposity restricts the descent of the diaphragm into the abdominal cavity which causes the incomplete expansion of the chest and thus the lungs, therefore increasing the thoracic pressure. ${ }^{[80,81]}$ All these lead to a reduction of chest wall compliance, ${ }^{[82,83]}$ increased respiratory effort due to added weight of breathing as the increased fat mass loads the respiratory apparatus that affects airway closure. ${ }^{[78,80,84,85,86]}$ All these lead to a negative impact on gaseous perfusion whereas abdominal fat deposition causes respiratory muscle dysfunction. ${ }^{[87]}$ Another study explained that obesity increased the oxygen consumption ${ }^{[78,85,88,89]}$ which was attributed to the fact that increased fat deposition in between the muscles and ribs might have increased the metabolic demand. [78]

Further, breathing mechanics involve contraction and descend of the diaphragm during inspiration to increase the vertical diameter of the thorax and intrathoracic negativity. In this connection, trunk obesity is more important than the overall adipose tissue represented by BMI. $\mathrm{WC}$, as a measure of abdominal fat deposition, is therefore, reported to have more consistent predictability for pulmonary function than BMI that does not distinguish between fat mass and muscle mass. ${ }^{[78]}$

In the Gynoid Group, using a Pearson product-moment correlation test on the data $(r=0.31$, df $=48)$, shows that the results were not significant $(\mathrm{p}<0.025$ for a one-tailed test). This means there is a negative correlation between PEFR and WHR (the higher the WHR, the lower the range of PEFR). This negative association of PEFR with obesity markers particularly WC and WHR is representing primary restrictive lung function pattern. This restrictive pattern may be the result of limited diaphragmatic decent or could be because of diminished rib cage movement and thoracic compliance due to fat deposition in the chest wall. Both of these mechanisms lead to restricted respiratory movement. ${ }^{[20]}$ Further, significantly higher values of WHR shown by the pre-obese and obese groups of a study were due to the result of decreased physical activity and sedentary life style of these subjects as it is reported that, increased physical activity is related to lower WHR in young adult men and women ${ }^{[90]}$ and we noticed a similar association too since our subjects also lived a sedentary lifestyle with decreased physical activity.

\section{Observation 5: Shows Correlation between PEFR and WHtR in Both the Groups}


Graphs 7, 8 \& Table 5, show that using a Pearson product moment-correlation test on the data $(\mathrm{r}=-0.17$, df $=48)$, the results were not significant $(\mathrm{p}>0.025$ for a one-tailed test) in the Android Group and ( $\mathrm{r}$ $=0.02, \mathrm{df}=48)$ the results were also not significant $(\mathrm{p}>0.025$ for a one-tailed test) in the Gynoid Group. This means there is a positive correlation between PEFR and WHtR (the higher the WHtR, the higher the range of PEFR) in both the Groups. According to Malhotra, et al. ${ }^{[91]}$ the heavier the person, the need for oxygen will increase. Increased oxygen demand must be met by a ventilation system, which will improve respiratory function and PEFR. The waist-height ratio, in principle, is a good measure to represent the waist circumference in relation to another easily measurable body proportion so that distortions based on the body frame size in different populations are removed [92] Height, Weight, and Chest circumference are the main determinant factors of PEFR among the physical parameters. ${ }^{[93,94]}$ The previous studies have proved that it is a good parameter of central obesity and an increase of which indicates the risk for cardiometabolic disorders ${ }^{[95]}$ The results of a study also suggests that it can serve as a good marker in pulmonary function study. ${ }^{[41]}$ However, the different studies carried by Joshi et al., ${ }^{[96]}$ Saxena Y et al. ${ }^{[97]}$ noticed a negative relation between adiposity markers and lung function parameters other than PEFR. Variation in the results could be since not many studies have assessed the correlation of PEFR and WHtR in Android and Gynoid female subjects between the ages of 20-40 years.

Observations 6, 7: Represent values of the Linear Regression between PEFR with BMI, WHR \& WHtR in Android and Gynoid Group \& Unpaired T-Test between PEFR in Both the Groups

Table 5 shows the Linear Regression test on the data: In the Android Group, the results were significant between PEFR \& BMI and were not significant between
PEFR \& WHR and with PEFR \& WHtR. In the Gynoid Group, the results were significant between PEFR \& WHR and were not significant between PEFR \& BMI and with PEFR \& WHtR.

From Graph $9 \&$ Table 6, it is seen that using an Unrelated $\mathrm{t}$-Test on the data $(\mathrm{t}$ $=2.137, \mathrm{df}=98$ ) the results were found to be Significant $(\mathrm{p}<0.05$ for a one-tailed hypothesis) between mean values of PEFR in Android and Gynoid Group. The Null hypothesis can therefore be rejected. This means that there is a difference in Peak Expiratory Flow Rate between Android and Gynoid Obesity in Females.

Gynoid PEFR is better by $5.6 \%$ than Android PEFR. PEFR is influenced by gender, body surface area, obesity, physical activity, posture, environment \& racial differences $[98,99,100,101]$ and also by individual's physical. The elementary factors upon which PEFR values depend are voluntary effort, the strength of the expiratory muscles, generating the force of contraction, lung volume and airway size, and elastic recoil strength of the lungs. ${ }^{[88,}$ 100,102, 103] Although, it's an established fact that forced expiratory volume over $1 \mathrm{sec}$ (FEV1) is more efficient and accurate than PEFR for indicating airway obstruction. However, PEFR due to its portability, costeffectiveness, feasibility, and simplicity of maneuver, has made it preferable over FEV1. ${ }^{[104]}$ The Mini Peak Flow Meter is a useful instrument that is widely used for ambulatory PEFR measurement. ${ }^{[104]}$

Increased central adiposity in women has been associated with relative androgen excess, ${ }^{[45]}$ which could be seen in Android Females and thus could yield lesser PEFR values when compared to their Gynoid counterparts. Excess weight on the anterior chest wall due to obesity lowers chest wall compliance and respiratory muscle endurance with an increase in work of breathing and airway resistance. ${ }^{[15,27,105]}$ Furthermore, the buildup of adipose tissue in the anterior abdominal wall and in the intra-abdominal visceral tissue hinders diaphragmatic movement, diminishes basal 
lung expansion during inspiration, and with the closure of peripheral lung units, causing ventilation-perfusion abnormalities and arterial hypoxemia. ${ }^{[20,31]}$ Thus, PEFR in the Android Type of fat distribution would be affected more than the Gynoid Type as seen from the results of the present study.

\section{CONCLUSION}

From the present study, we conclude that there is a correlation between PEFR and Android Obesity, PEFR and Gynoid Obesity and there is a difference in Peak Expiratory Flow Rate between Android and Gynoid Obesity in Females. The PEFR in the Gynoid Group is $5.6 \%$ better than PEFR in the Android Group.

\section{CLINICAL IMPLICATIONS}

$>$ Detect early warning signs in at-risk populations. Ex. Obese subjects.

$>$ Diagnostic: Screening at Females for risk factors of Android and Gynoid Obesity.

> Prognostic: Assessment of degree/severity of disease and disability, evaluating the effectiveness of treatment/exercise program and determining further treatment goals.

$>$ Assessment of PEFR routinely in Young Females with Obesity to prevent Cardiovascular and Respiratory complications.

\section{LIMITATIONS}

$>$ A Small Sample Size was chosen due to difficulty in finding the subjects especially those with Type 3 Obesity.

$>$ The study design was cross-sectional and hence did not include a follow up assessment. The study did not assess factors that predict long-term outcome for example, if reducing weight would increase the PEFR value in the Female Obese Subjects.

$>$ Additional factors that have been suggested to contribute to Obesity were not included in this study like comorbidities, genetics, sleep, food, lifestyle, activity, medications, environment, emotional factors etc

\section{SUGGESTIONS}

A Larger Sample Size should be chosen.

Interventional studies examining the Reduction of weight and its effect on changes in Lung Function can be assessed in future studies.

Factors contributing to Obesity like comorbidities, genetics, sleep, food, lifestyle, activity, medications, environment, emotional factors etc should be included in further studies.

\section{Acknowledgement: None Conflict of Interest: None Source of Funding: None Ethical Approval: Approved}

\section{REFERENCES}

1. World Health Organization Tech Rep Series, 854. Overweight adults. In: Physical status: The use and interpretation of anthropometry; 1995:312-4.

2. Pandey RM, Gupta R, Misra A, Misra P, Singh V, Agrawal A, et al. Determinants of urban-rural differences in cardiovascular risk factors in middle-aged women in India: a cross-sectional study. Int J Cardiol. 2013; 163:157-62.

3. Deepa R, Sandeep S, Mohan V. Abdominal obesity, visceral fat and type 2 diabetesAsian Indian phenotype. In: Mohan V, Rao GHR, editors. Type 2 diabetes in South Asians: epidemiology, risk factors and prevention. New Delhi, India: Jaypee Brothers Medical Publishers (P) Ltd; 2006. pp. $138-52$.

4. Misra A, Pandey RM, Devi JR, Sharma R, Vikram NK, Khanna N. High prevalence of diabetes, obesity and dyslipidaemia in urban slum population in northern India. Int $\mathbf{J}$ ObesRelatMetabDisord. 2001; 25:1722-9.

5. Zargar AH, Masoodi SR, Laway BA, Khan AK, Wani AI, Bashir MI, et al. Prevalence of obesity in adults: an epidemiological study from Kashmir valley of Indian subcontinent. J Assoc Physicians India. 2000; 48:1170-4.

6. Shukla HC, Gupta PC, Mehta HC, Hebert JR. Descriptive epidemiology of body mass 
index of an urban adult population in western India. J Epidemiol Community Health. 2002; 56:876-80.

7. Singh RB, Pella D, Mechirova V, Kartikey K, Demeester F, Tomar RS, et al. Five City Study Group. Prevalence of obesity, physical inactivity and undernutrition, a triple burden of diseases during transition in a developing economy. The Five City Study Group. ActaCardiol. 2007; 62:119-27.

8. Christopher Zammit Helen Liddicoat Ian MoonsieHimenderMakker. Obesity and respiratory diseases. Sleep and Ventilation Unit, Department of Respiratory Medicine, North Middlesex University Hospital, London, UK International Journal of General Medicine 20 October 2010

9. Chen Y, Rennie D, Cormier YF, Dosman J. Waist circumference is associated with pulmonary function in normal-weight, overweight, and obese subjects. Am J ClinNutr 2007; 85:35-9

10. Unterborn J. Pulmonary function testing in obesity, pregnancy, and extremes of body habitus. Clinics in Chest Medicine 2001; 22:759-767.

11. Brozak $\mathrm{J}$ and Keys A. The evaluation of leanness-fatness in man: norms and interrelationships. Food and agricultural organization of the United Nations. Dietary Surveys, 1949: Vol-62(3)194-206.

12. Chen R, Tunstall-Pedoe H, Bolton-Smith C, Hannah MK, Morrison C. Association of dietary antioxidants and waist circumference with pulmonary function and airway obstruction. Am J Epidemiol2001: 153:157-63.

13. Chen Y, Horne S, Dosman J. Body weight and weight gain related to pulmonary function decline in adults: A 6 year follow up study. Thorax 1993; 48:375-80.

14. World Health Organization (WHO), International Association for the Study of Obesity (IASO), and International Obesity Task Force (IOTF). The Asia- Pacific Perspective: Redefining Obesity and Its Treatment. 2000; Australia:Health Communication Pvt Ltd pp 17-19.

15. McClean KM, Kee F, Young IS, Elborn JS. Obesity and the lung: 1. Epidemiology. Thorax. 2008; 63:649-654.

16. Thornhill. The Evolutionary Biology of Human Female Sexuality.

17. Ley, CJ; Lees, B; Stevenson, JC (1992). "Sex-and menopause-associated changes in body-fat distribution". American Journal of Clinical Nutrition. 55(5): 950-954.

18. Wells, JCK (2007). "Sexual dimorphism of body composition". Best Practice \& Research Clinical Endocrinology \& Metabolism.21 (3): 415-430.

19. Wysocki, M; Krotkiewski, M; Braide, M; Bagge, U (3 January 1991). "Hemorheological disturbances, metabolic parameters and blood pressure in different types of obesity". Atherosclerosis.88 (1): 21-28.

20. Wannamethee SG, Shaper AG, Whincup PH. Body fat distribution, body composition, and respiratory function in elderly men. Am J ClinNutr. 2005; 82:9961003.

21. Despres JP, Lemieux I (2006) Abdominal obesity and metabolic syndrome. Nature 444:881-7.

22. Fox CS, Massaro JM, Hoffmann U, Pou KM, Maurovich-Horvat P, et al. (2007) Abdominal visceral and subcutaneous adipose tissue compartments: association with metabolic risk factors in the Framingham Heart Study. Circulation 116: $39-48$.

23. Pi-Sunyer FX (2004) The epidemiology of central fat distribution in relation to disease. Nutr Rev 62: S120-S126.

24. Canoy D (2008) Distribution of body fat and risk of coronary heart disease in men and women. CurrOpinCardiol 23: 591-8.

25. Kim SK, Park SW, Hwang IJ, Lee YK, Cho YW (2010) High fat stores in ectopic compartments in men with newly diagnosed type 2 diabetes: an anthropometric determinant of carotid atherosclerosis and insulin resistance. Int $\mathrm{J}$ Obes (Lond) 34:105-10.

26. Leone N, Courbon D, Thomas F, et al. Lung function impairment and metabolic syndrome. The critical role of abdominal obesity. Am J RespirCrit Care Med. 2009; 179:509-516.

27. Ochs-Balcom HM, Grant BJ, Muti P, et al. Pulmonary function and abdominal adiposity in the general population. Chest. 2006; 129: 853-862.

28. Waist Circumference and Waist-Hip Ratio Report of a WHO Expert Consultation Geneva, 8-11 December 2008

29. Gibson GJ. Obesity, respiratory function and breathlessness. Thorax. 2000; 55:S41S44. 
30. CM Lee, Huxley RR, Wildman RP, Woodward M (July 2008). Indices of abdominal obesity are better discriminators of cardiovascular risk factors than BMI: a meta-analysis. Journal of Clinical Epidemiology. 61(7): 646-653.

31. Malhotra A, Hillman D. Obesity and the lung: 3. Obesity, respiration and intensive care. Thorax. 2008; 63:925-931.

32. Jain SK, Kumar R, Sharma DA. Peak Expiratory flow rates (Peak Expiratory Flow Rate) in healthy Indian adults: A statistical evaluation -I. Lung India 1983; 3: 88-91.

33. American Thoracic Society: Standardization of Spirometry; 1994 update. Amer J Respir\& Critical Care Med 1995; 152: 1107-1136.

34. M. B. Dikshit, S. Raje and M. J. Agrawal. Lung Functions with Spirometry: An Indian Perspective-1. Peak Expiratory Flow Rates. Indian J Physiolpharmacol 2005: 49 (1): 818.

35. Gibson LJ, Peto J, Janet M Warren JM, Silva IdosS. Lack of evidence on diets for obesity for children: a systematic review. Int J Epidemiol December 2006; 35:1544-52.

36. Dungel KU, Parthasarathy D, DipaliS.Peak expiratory flow rate of Nepalese children and young adults. Kathmandu University Medical Journal 2008; 6:346-54.

37. Sharpjt, Henry JP, Sweanysk, Meadows WR, Pietrasrj. Effects of mass loading the Respiratory system in man. J ApplPhysiol (1985).1964 Sep: 19:959-66.

38. Guenette JA, Jensen D, O'Donnell DE. Respiratory function and the obesity paradox. CurrOpinClinNutrMetab Care.2010 Oct 31; 13(6):618-24.

39. K. Park, Obesity, Park textbook of Preventive and social Medicine, 21st edition, Feb 2011, 366-370.

40. Physiology of Sport and Exercise. W. Larry Kenney, Jack H. Wilmore, David L. Costill $5^{\text {th }}$ Edition 2012

41. Kanavi Roopa Shekharappa, Smilee Johney S, Vedawathi KJ. Impact of obesity on peak expiratory flow rate in different age groups. Dept. of Physiology, JJM Medical College, Davengere, Karnataka

42. S Suganya and V Philominal. Influence of body mass index on peak expiratory flow Rate. International Journal of Applied Research 2016; 2(8): 518-521

43. Kumar D, Puri R, Sinha N, HasanSN, Agarwal V, Mishra SB. Peak expiratory flow rate assessment in obese and non-obese subjects in western Uttar Pradesh. IJRRMS 2013; 3(3)

44. Delowar Hossain, Selina Khanum, Choudhury Ali Kawser. Relationship of Obesity and Peak Expiratory Flow Rate (Peak Expiratory Flow Rate) amongst 8-15 Years Old School Children. Bangladesh J Child Health 201: VOL 39 (2): 77-81

45. Dr. Kalpojit Saikia, Dr. Shrabani Barman. Study of the effect of Body Mass Index (BMI) on Peak Expiratory Flow Rate (Peak Expiratory Flow Rate) in Young Healthy Individuals. GJRA, Volume 5, Issue 9, September - 2016.

46. IGPS Aryana, KAW Nugraha, AAGORK Putra, IAJD Kusumawardani, RAT Kuswardhani, N Astika, IB Putrawan, R Purnami, IGNB Artana, IBN Rai. The Association between Central Obesity and Peak Expiratory Flow Rate (Peak Expiratory Flow Rate) in Elderly at Pedawa Village, Buleleng, Bali, Indonesia. EPH International Journal of Medical and Health Science, Volume-4, Issue-2nd February 2018

47. Syed Najamuddin Farooq, Shaikh Muhammad Amir Mustafa, Ammad Ahmed, Waheeb Al Harbi, Abdul Halim Salim Serafi, Muhammad Irfan Safi Rizvi. The effect of Obesity Markers on Peak Expiratory Flow Rate in Young Saudi Adults. Farooq S. N. et al., Med. Res. Chron., 2015, 2 (1), 126-134

48. Hasnain Abbas Dharamshi, Ahmad Faraz, Erum Ashraf, Ali Abbas Mohsin Ali, Mansoor Ali Merchant Rameez, Syed Muhammad Ali Abidi, Saad Ullah, Mustaqueem Ur Rehman, Taha Nafees. Variation of Peak Expiratory Flow Rate with Body Mass Index in Medical Students of Karachi, Pakistan. International Archives of Medicine, Vol. 8 No. 121 doi: 10.3823/1720.

49. Surendra BV, Shobha Rani V. Variation of peak Expiratory Flow Rate with Body Mass Index in the first year male Medical Students of Viswabharathi Medical College, Kurnool. Int. j. clin.biomed. res 2017: 3(4): 14-17.

50. Dr. Jayanti Mishra, Dr. Soumya Mishra, Dr. Sudeep Satpathy, Dr. Magna Manjareeka, Dr. Prakash Kumar Nayak, Dr. Prabhabati Mohanty. Variations in Peak Expiratory Flow Rate among Males and Females With 
Respect To Anthropometric Parameters. IOSR Journal of Dental and Medical Sciences (IOSR-JDMS) Volume 5, Issue 1 (Mar - Apr 2013), PP 47-50.

51. Peder Wiklund, Fredrik Toss, Lars Weinehall, Go" ran Hallmans, Paul W. Franks, Anna Nordstro"m, Peter Nordstro"m. Abdominal and Gynoid Fat Mass Are Associated with Cardiovascular Risk Factors in Men and Women. J Clin Endocrinol Metab. November 2008, 93(11):4360-4366

52. Seon Mee Kang, Ji Won Yoon, Hwa Young Ahn, So Yeon Kim, Kyoung Ho Lee, Hayley Shin, Sung Hee Choi, Kyong Soo Park, Hak Chul Jang, Soo Lim. Android Fat Depot Is More Closely Associated with Metabolic Syndrome than Abdominal Visceral Fat in Elderly People. November 2011, Volume 6, Issue 11, e27694

53. Saraswathi Ilango, Christy A, Saravanan A, Dr. Prema Sembulingam Correlation of Obesity Indices with Peak Expiratory Flow Rate in Males and Females. IOSR Journal of Pharmacy, Volume 4, Issue 2(February 2014), Pp 21-27.

54. M. B. Dikshit, S. Raje and M. J. Agrawal. Lung Functions with Spirometry: An Indian Perspective-1. Peak Expiratory Flow Rates. Indian J Physiol pharmacol 2005: 49 (1): 818.

55. Dr. Nirupama Moran. Study the Effect of Body Mass Index [Bmi] On Peak Expiratory Flow Rate [Pefr] In 20 - 30 Years Age Group. Journal of Dental and Medical Sciences (IOSR-JDMS) e-ISSN: 2279-0853, Volume 14, Issue 7, Ver. VI (July. 2015), PP 86-89.

56. Sunil Kumar Jena, Meena Mirdha, Purnima Meher, Akshaya Kumar Misra. Relation of peak expiratory flow rate to body mass index in young adults. Muller Journal of Medical Sciences and Research | Vol 8 | Issue 1 | January - June 2017.

57. Yogesh Saxena, Brijesh Purwar, Rashi Upmanyu. Adiposity: Determinant of Peak Expiratory Flow Rate in Young Indian Adults Male. The Indian Journal of Chest Diseases \& Allied Sciences, Vol.53: 2011.

58. Kamal R, Kesavachandran C, Bihari V, Sathian B, Srivastava AK. Alterations in lung functions based on BMI and Body fat percentage among obese Indian population at National Capital Region. Nepal J Epidemiol. 2015: 5(2); 470-479.
59. He, Qing, Mary Horlick, John Thornton, Jack Wang, Richard N. Pierson, JR., Stanley Heshka, And Dympna Gallagher. Sexspecific fat distribution is not linear across pubertal groups in a multiethnic study. Obes Res. 2004; 12:725-733.

60. Basuli Goswami, Anindita Singha Roy, Rishna Dalui, and Amit Bandyopadhyay. Peak Expiratory Flow Rate - A Consistent Marker of Respiratory Illness Associated with Childhood Obesity. American Journal of Sports Science and Medicine, vol. 2, no. 1 (2014): 21-26. doi: 10.12691/ajssm-2-1-4.

61. 2008 Physical Activity Guidelines for Americans. Office of Disease Prevention \& Health Promotion, U.S. Department of Health and Human Services.

62. Jnaneshwara Panduranga Shenoy, J. Shivakumar, B. Kalpana, Shankar K. Bhat. Impact of adiposity markers on Peak expiratory flow rate in young adult South Indian females. Muller Journal of Medical Science and Research, Vol 5, Issue 2, Jul Dec 2014.

63. Who expert consultation. Appropriate bodymass index for Asian populations and its implications for policy and intervention strategis. The Lancet - Vol 363 - January 10,2004

64. Molarius A, Seidell JC, Sans S, Tuomilehto J, Kuulasmaa K. Waist and hip circumferences, and waist-hip ratio in 19 populations of the Who Monica Project. Int J Obes Relat Metab Disord.1999 Feb: 23(2):116-25

65. B. Srilakshmi Dietectics $8^{\text {th }}$ Edition, pg 230

66. Shenoy J P, J Shivakumar2, Kalpana B3, Bhat S K3. Impact of adiposity markers on Peak expiratory flow rate in young adult South Indian females. 2014 Vol 5(2):121124.

67. Christian S B, Chavda B, Trivedi, Sudha Parmar, Sorani A, Panchal B. Effect of BMI on pulmonary function tests in young adults. International Journal of Basic \& Applied Physiology 2014; Vol 3(1):165.

68. Anuradha R Joshi, Ratan Singh, JOSHI AR. Correlation of Pulmonary function tests with Body Fat percentage in young individuals, Indian J Physiol Pharmacology. 2008: 52(4):383-388

69. King GG, Brown NJ, Diba C, et al. The effects of body weight on airway caliber. Eur Respir Journals. 2005; 25: 896-901. 
70. Sexual differentiation. A determinant factor of the forms of obesity. Jean Vague. Marseilles.

71. Bergman BC, Cornier MA, Horton TJ, BessesenDH2007 Effects of fasting on insulin action and glucose kinetics in lean and obese men and women. Am J Physiol Endocrinol Metab 293:E1103-E111

72. Nielsen S, Guo Z, Johnson CM, Hensrud DD, Jensen MD 2004 Splanchnic lipolysis in human obesity. J Clin Invest 113:15821588

73. Fain JN, Madan AK, Hiler ML, Cheema P, Bahouth SW 2004 Comparison of the release of adipokines by adipose tissue, adipose tissue matrix, and adipocytes from visceral and subcutaneous abdominal adipose tissues of obese humans. Endocrinology 145:2273-2282

74. Fried SK, Bunkin DA, Green berg AS1998O mental and subcutaneous adipose tissues of obese subjects release interleukin6: depot difference and regulation by glucocorticoid. J Clin Endocrinol Metab 83:847-850

75. Eckel RH, York DA, Rossner S, Hubbard V, Caterson I, St Jeor ST, Hayman LL et al. American Heart Association. Prevention Conference VII: Obesity, a worldwide epidemic related to heat disease and stroke: executive summary. Circulation 2004; 10:2968-2975.

76. McCarty MF 2003 A paradox resolved: the postprandial model of insulin resistance explains why gynoid adiposity appears to be protective. Med Hypotheses 61:173-176 [77] Tanko LB, Bagger YZ, Alexandersen P, Larsen PJ, Christiansen C 2003 Peripheraladiposityexhibitsanindependentdo minantantiatherogeniceffectin elderly women. Circulation 107:1626-1631

77. Parameswaran K, Todd DC, Soth M. Altered respiratory physiology in obesity. Can Respir J 2006; 13:203-10.

78. Zerah F, Harf A, Perlemuter L, Lorino H, Lorino AM, Atlan G. Effects of obesity on respiratory resistance. Chest 1993; 103:1470-6.

79. Siregar, F.Z., Panggabean, G., Daulay, R.M., Lubis, H.M., "Comparison of peak expiratory flow rate (PEFR) before and after physical exercise in obese and non-obese children", Paediatrica Indonesiana, 49(1). Jan., 20-4, 2009.
80. Saxena, Y., Purwar, B., Upmanyu, R., "Adiposity: Determinant of Peak Expiratory Flow Rate in Young Indian Adults Male", The Indian Journal of Chest Diseases \& Allied Sciences, 53, 29-33, 2011.

81. Paralikar, S.J., Kathrotia, R.G., Pathak, N.R., Jani, M.B., "Assessment of pulmonary functions in obese adolescent boys", Lung India, 29(3). Jul-Sep., 236-40, 2012.

82. Nageshwari, K., Sharma, R., Kohli, D.R., "Assessment of respiratory and sympathetic cardiovascular parameters in obese school children", Indian Journal of Physiology and Pharmacology, 51. 235-43. 2007.

83. Gundogdu Z, Eryilmaza N, "Correlation between peak flow and body mass index in obese and non-obese children in Kocaeli, Turkey", Primary Care Respiratory Journal, 20. 403-6, 2011.

84. Lin, C.K., Lin, C.C., "Work of breathing and respiratory drive in obesity, Respirology (Carlton, Vic.)", 17(3). 402-11. 2012.

85. Sood, A., "Obesity, adipokines, and lung disease". Journal of Applied Physiology, 108(3), 744-53, 2010.

86. Tenório, L.H.S., Santos, A.C., Oliveira, A.S., Lima, A.M.J., Brasileiro, M.S., "Obesity and pulmonary function tests in children and adolescents: a systematic review", Revista Paulista de Pediatria, 30(3). 423-30. 2012.

87. Salome, C.C.M., King, G.G.G., Berend, N., "Physiology of obesity and effects on lung function", Journal of Applied Physiology, 108(1). 11. 2006.

88. Naimark, A., Cherniack, R., "Compliance of the respiratory system and its components in health and obesity", Journal of Applied Physiology, 15, 377-382, 1960.

89. Tremblay AA, Després JPJ, Leblanc CC, Craig CLC, Ferris BB, Stephens TT, et al. Effect of intensity of physical activity on body fatness and fat distribution. Am $\mathrm{J}$ ClinNutr 1990 Jan 31; 51(2):153-7.

90. Malhotra V, Srinivasaragavan N, Patil R, Jaiganga R. Correlation of peak expiratory flow rate with anthropometric parameters in young adults. International Journal of Current Research and Review. 2011: 3(11):149-54

91. Kuriyan R, Thomas T, Lokesh DP, Sheth NR, Mahendra A, Joy R, et al. Waist circumference and waist for height percentiles in urban South Indian children 
aged 3-16 years. Indian Pediatr 2011; 48:765-71.

92. Jaja SI, Ojo GO. Peak flow rate in young Nigerian adults. Nigerian Journal of Physiological Sciences 1983; 1: 24-30.

93. Mungreiphy NK. Ethnicity obesity and health pattern among Indian population. Journal of Natural science, Biology and Medicine 2012; 3:52-59.

94. Babb TG, Wyrick BL, deLorey DS, Chase PJ, Young MY. Fat distribution and endexpiratory lung volume in lean and obese men and women. Chest. 2008; 134:704711.

95. Joshi A, Singh R, Joshi AR. Correlation of pulmonary function tests with body fat percentage in young individuals. Indian $\mathbf{J}$ Physiol Pharmacol 2008; 52:383-8.

96. Saxena Y, Sidhwani G, Upmanyu R. Abdominal obesity and pulmonary functions in young Indian adults: A prospective study. Indian J Physiol Pharmacol 2009; 53:31826.

97. Benjaponpitak, S., Direkwattanachai, C., Kraisarin, C., Sasisakulporn, C., "Peak expiratory flow rate values of students in Bangkok", J Med Assoc Thai, 82(Supp.l). 137-43. 1999.

98. Rangnathan, S., Li, C., Wood, L., Rangnathan, G., "Adipose tissue tumor necrosis factor and interleukin-6 expression in human obesity and insulin resistance", American Journal of Physiology and Endocrinology Metabolism, 280.745-51. 2001.
99. Shaheen, S.O., Sterne. J.A.C., Montgomery, S.M., Azima. H.A., "Birth weight, body mass index and asthma in young adults", Thorax, 54. 396-402. 1999.

100. Siregar, F.Z., Panggabean, G., Daulay, R.M., Lubis, H.M., "Comparison of peak expiratory flow rate (PEFR) before and after physical exercise in obese and non-obese children", Paediatrica Indonesiana, 49(1). Jan., 20-4, 2009.

101. Gianinis. H.H., Bianca. O., Collins, L.C., Hoberty, P.D., Walker. J.F., Fletcher. E.C., Peiris. A.N., "The effects of body fat distribution on pulmonary function tests", Chest, 107. 1298-302. 1995.

102. Raju, P.S., Prasad, K.V., Ramana, Y.V., Murthy, K.J., "Pulmonary function tests in Indian girls prediction equations", Indian Journal of Pediatrics, 71. 893-7. 2004.

103. Mittal S, Gupta S, Kumar A, Singh KD. Regression equations for peak expiratory flow in healthy children aged 7 to 14 years from Punjab, India. Lung India. 2013 JulSep; 30(3): 183-186.

104. Babb TG, Ranasinghe KG, Comeau LA, Semon TL, Schwartz B. Dyspnoea on exertion in obese women. Am J RespirCrit Care Med. 2008; 178:116 - 123.

How to cite this article: Shah S, Gaikwad P. Comparison of peak expiratory flow rate between android and gynoid pattern obesity in females. Int J Health Sci Res. 2021; 11(4): 236254. DOI: https://doi.org/10.52403/ijhsr. 20210429

\section{Appendix: CASE RECORD FORM}

Comparison of Peak Expiratory Flow Rate between Android and Gynoid Obesity in Females

NAME:

AGE:

WEIGHT:

HEIGHT:

BMI:

GRADE:

WAIST CIRCUMFERENCE (WC):

HIP CIRCUMFERENC (HC):

WAIST TO HIP RATIO (WHR):

WAIST TO HEIGHT RATIO (WtHR):

PEAK EXPIRATORY FLOW RATE:

\begin{tabular}{|c|c|}
\hline 1. & \\
\hline 2. & \\
\hline 3. & \\
\hline HIGHEST OF 3 READINGS & \\
\hline
\end{tabular}

